\title{
DEVELOPMENT OF A NEW TOURIST DESTINATION BY BUILDING A NEW RAILWAY INFRASTRUCTURE
}

\author{
RADOS, B.
}

Abstract: The introduction of a new railway infrastructure should be a generator of an economically sustainable tourist development. The priority is an analysis of economic and social factors of the territory where the new infrastructure will be implemented. In the same time on the territory in question it is required to investigate the traffic demand of passenger and cargo transport and the consequences of the new railway infrastructure implementation regarding environment control. The concept of sustainable tourist development indicates a necessity of optimal use of environment resources that are the foundation of tourist development and by doing that keeping the important ecological processes intact and helping the protection and preservation of natural heritage and biodiversity. Traffic planning cannot be founded on pure satisfaction of traffic demand anymore hence it has to control traffic growth and channel it through the modelling of options of sustainable development.

Key words: tourism, sustainable development, railway, infrastructure, economy
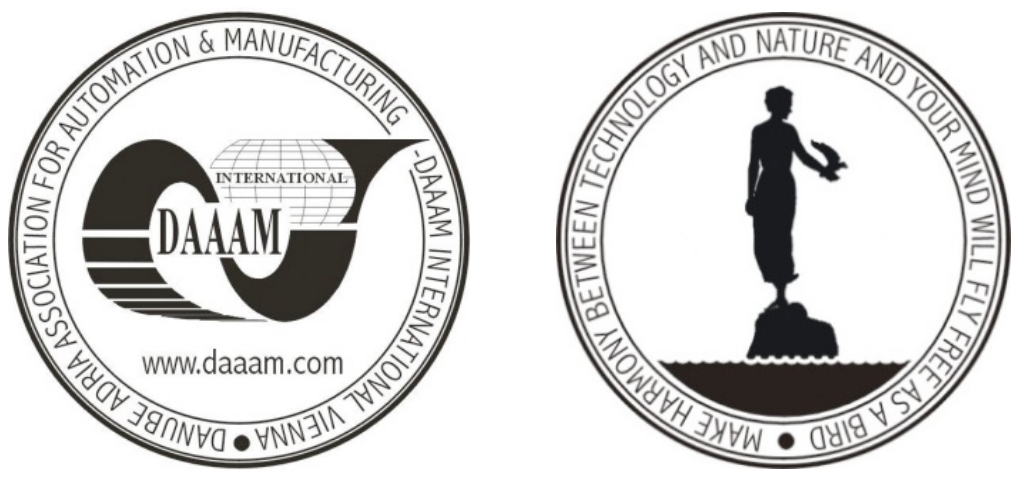

Authors' data: Mr.sc. Rados, B[ozica]; Tehnicka skola Zagreb, Palmoticeva 84, 10 000,Zagreb, Croatia, bozica.rados@gmail.com

This Publication has to be referred as: Rados, B[ozica] (2014). Development of a New Tourist Destination by Building a New Railway Infrastructure, Chapter 05 in DAAAM International Scientific Book 2014, pp.063-070, B. Katalinic (Ed.), Published by DAAAM International, ISBN 978-3-901509-98-8, ISSN 1726-9687, Vienna, Austria

DOI: $10.2507 /$ daaam.scibook.2014.05 
Rados, B.: Development of a New Tourist Destination by Building a New Railway ...

\section{Introduction}

Traffic planning, that essentially has to be under the authority of the traffic sciences, cannot be founded and used as a pure traffic demand tool anymore but as a tool with which one controls the traffic growth and can channel it by modelling the options sustainable growth. The methodology of strategic traffic planning is founded on the complex of influential factors. It also implies a sistemic research of the wider problems such as geotraffic and traffic flow dynamics analysis and elements of traffic policy - infrastructure, maintenance and regulations; external traffic expenses; security and enviromental protection in traffic; specificities of urban traffic and urban planning; new technologies used as a tool in traffic development; transport of acquits etc. In that context the development of a new touristic destination is important for

Croatian tourismis who is substantially behind the modern european tendencies. The policies remaining from the old system and a general political instability have resulted in stagnation of croatian tourism. The basis of tourism prosperity lies in the emphasis on domestic offer, creation of a specific image and destination rethinking. Croatia must reposition itself and present itself as an attractive mediterranean destination that is capable of adjusting its offer even to the highest requistions. (The Development Strategy of Croatian Tourism, 2003).

The understanding of a traffic system requires an integrative intermodal approach and a certain knowledge of the foundations of sustainable growth. The implementation status of the directions of sustainable growth in Croatia currently shows a large number of uncoordinated projects on all levels, the inexsistence of a central body and monitoring mechanism of the results of implementary measures. Taking that into account the secundary objective of the thesis is status analysis. The thesis will produce an idea solution for the implementation of construction of the new railway Koprivnica-Kotoriba-Drzavna Granica and furthermore it will emphasise its position on the Mediterranean traffic corridor. For that developent it is a crutial thing to recognise that a secondary benefit is a developement of a touristic destination because tourism is an important economic driver. The project is a part of Study of Basic Possibility of new railway construction on the line Koprivnica - Kotoriba State border which is funding from Croatian railways as a part of a bigger project of modernisation of Port Rijeka, and creating a missing link form Port to Budapest on traffic corridor 5.c. The model will be used as a platform to test how an introduction of a completley new traffic vector, on a previously mentioned territory where the new railway will be placed, will create a completly new tourist destination and how the economic and social part of the territories in question changes.

Comprised within the solution there will be a projection of total cargo quantities - as generators of economy development - and number of local, international or tourist passengers on a traffic vector from Rijeka to Budapest. Based on prevoiusly mentioned thesis priorites we will also model, modify and test a macroscopic model of the implementation of construction of a new railway Koprivnica-Kotoriba-state border. The model will provide the economic and financial estimates accompanied with a enviromental impact study for the new railway construction. 


\section{Traffic position}

The object of the study was a research of basic possibilites of new railway construction on Koprivnica - Kotoriba - State border. The function of the new railway in international railway traffic was studied with traffic-technological idea solution. The influence of the new railway on regional traffic connection of northwest Croatia was also studied.

Railway on the the territory of Kotoriba is of historical significance. First railway in Croatia was built right through those territories. It was opened for public traffic on 24th April 1860. and it connected Velika Kaniza in Hungary with Pragersko in Slovenia. The part that was passing through Croatia was from Kotoriba, through Cakovec until Macinec and it was $41 \mathrm{~km}$ long.

The construction of that railway Kotoriba gained a larger significance cause of the increased passage of passengers from Koprivnica, Durdevci and Virovitica. It might have been important for Kotoriba but the new railway didn't connect Medimurje region with Zagreb rather with Velika Kaniza, Maribor, Ljubljana, Trieste, Graz and Vienna. Zagreb got a railway in 1862. but only as far to Zidani Most. Croatia is positioned on two corridors of Basic Traffic Network of EU, specifically on Mediterranean corridor and Rhine-Danube corridor. Mediterranean corridor connects the south of the Iberian penisola passing through spanish and french mediterranean coasts, Alps on the north of Italy, Slovenia and continuing towards Hungaro-Ucranian border. Its integral part is vector Rijeka-Zagreb-Budapest, ie. RH2 corridor. On the Mediterranean corridor there is a railway vector ZagrebSlovenija, ie. RH1 corridor. Corridor Rhine-Danube is river vector that connects Strassbourg, Frankfurt, Vienna, Bratislava, Budapest where one part of the corridor continues toward Romania and the other one continues down the Danube between Croatia and Serbia and further on untill the Black Sea.

Railway DG-Botovo-Zagreb-Rijeka is, with other railways on the RH1 corridor, one of the most important railways in Croatia. It is a railway that connects the most important croatian port, Rijeka, with the inland. On the territory of Croatia the railway streches from Rijeka, through Zagreb up until Botovo which is on the border with Hungary. The connection of the Mediterranean corridor on the observed territory is a railway M501 DG-Cakovec-Kotoriba-DG. Railway KoprivnicaKotoriba would connect the exsisting railways M201 DG-Botovo-Dugo Selo and M501 DG-Cakovec-Kotoriba-DG. It would also have a certain regional significance in terms of connecting the northwest of Croatia with passenger and freight traffic augumenting the development the regions industrial zones. By constructing a new railway Koprivnica-Kotoriba-State border-Murakeresztur the croatian and hungarian parts of the Mediterranean corridor would connect and that would enable a direct connection of Rijeka port with railway network of the northwestern part of Hungary. In that area we have Sopron, a city with a significantly important logistical terminal and a depot train station. Sopron has become a center of allignement for traffic vectors originating from the southeast towards the west of the EU. It is connected with daily direct freight trains that go towards the ports of the North Sea such as Rotterdam and Hamburg. 
Rados, B.: Development of a New Tourist Destination by Building a New Railway ...

\section{Traffic necessities of observed territory - market research}

New railway Koprivnica - Kotoriba would pass through two regions, the Koprivnicko-krizevacka zupanija and Medimurska zupanija. It would connect two centers, Koprivnica and Kotoriba, and would pass through Koprivnicki Ivanec, Zablatje and Donja Dubrava. The analysis of observed area has produced dana that indicate a need for better connection with the capital, Zagreb. Due to changes occuring in state economy, impossibility of adequate education and scarsity of job offers the analysis has shown a large migration index of students and workers via Zagreb and, logically, that the optimization of traffic infrastructure would increase the development of economy, especially terciary services. Koprivnicko-krizevacka region with its surface of $1.748 \mathrm{~km}^{2}$ is seventeenth by size in Croatia and with the popoulation of 115.582 it arrives on the sixteenth place on state level. On the territory of the region in question the new railway would pass through the city of Koprivnica and through the municipalities of Koprivnicki Ivanec, Delekovec and Legrad. Medimurska region is bounded by two natural barriers, river Mura on the north and east and river Drava on the south. With the surface of just $730 \mathrm{~km}^{2}$ and the population of 118.426 it is the most densly populated region in Croatia. It is divided between three cities(Cakovec, Prelog, Mursko Sredisce) and 22 municipalities. The new railway should pass through the municipalities of Donja Dubrava and Kotoriba.

In 2011. there were 326.821 trains completed(passengers and goods) out of 345.000 that were planned.

In the year 2011. there were in total 335.261 trains operated on state railways, in 2009. 346.885, in 2008. 363.817 and in 2007. 364.740.

For freight transport in 2011. there were in total 72.000 trains forseen but only 65.919 were completed.

In 2010. there were in total 70.162 freight trains, in 2009. 75.824, in 2008. 91.643 and in 2007. 99.384.

Train kilometers of freight trains completed in 2011. were 5.370.580, in 2010 . 5.987.325, in 2009. 5.894.633, in 2008. 7.077.805 and in 2007. 7.535.012.

In 2011. there were 12.094.000 tons of goods transported, in 2010. 12.609.000 tons, in 2009. 11.661.000 tons, in 2008. 16.184.000 tons and in 2007. 17.231.000 tons.

For passenger traffic in 2011. there were 260.902 trains completed out of 273.000 that were planned.

In 2010. there were 265.099 passenger trains completed, in 2009. 271.061, in 2008. 272.174 and in 2007. 265.356.

Passenger trains kilometers made in 2011. were 18.108.767, in 2010. 18.791.095, in 2009. 18.896.384, in 2008. 19.104.657 and in 2007. 18.937.683.

In 2011. there were 49.083.000 passengers transported, in 2010. 69.564.000, in 2009. 73.650.000, in 2008. 70.961.000 and in 2007. 63.143.000.

In the last few years there was a significant increase in passenger transport especially in the years 2007., 2008. and 2009. while in 2010. there was a $5.41 \%$ decrease in respect to 2009.

The number of passengers transported continues to decline so much that in 2011. there was a $20.96 \%$ decline in the number of passengers. 
Suburban traffic in 2011. makes $58.92 \%$ of total passenger transport, in 2010. it was as high as $71.80 \%$. By doing the comparison of total transport of passengers made in 2011. with the one from 2009. there is a $55 \%$ decline. This is due to constantly decreasing standard of citizens ie. increased poverty and motionless economy.

The reasons for the decline in number of passengers in suburban transport are also high prices of tickets imposed by Zagreb's electrical tram(ZET) causing the effect of passengers buying only tram or only train tickets.

Total goods transport in 2011. is 12.09 millions of tons and is seeing a decline when comparing to previous years. In 2010. there were 12.61 millions of tons transported and in 2009. 12.76 millions of tons. The largest number of tons transported was in 2007. and it was 17.23 millions of tons. During the war years in 1992. there was 11.8 millions of tons transported. International freight transport started to recuperate in 2010. but in 2011. there was a $4.1 \%$ decrease in respect to 2010. Domestic transport sees an increase of $3.8 \%$ in respect to 2010 . The reason for this kind of transport is a general reduction of activities in economy especially in construction, chemical and processing industry. Generally the reasons for transport reduction should be looked for in the very economy of Croatia and also the economy of the world (Rados, 2014).

\section{Tourism as a generator of sustainable growth}

Improvement of the living standard has, among other things, caused the rise in fluctuation of tourists which has brought along the increase in tourist spending, i.e. the income from tourism. ( Pavlic, 2009).

The definition of tourism is a particularly arid pursuit' but important if one is to understand the nature, scope, impact and magnitude of global tourism. The terms 'travel' and 'tourism' are often interchanged within the published literature on tourism, but they are normally meant to encompass the field of research on human and business activities associated with one or more aspects of the temporary movement of persons away from their immediate home communities and daily work environments for business, pleasure or personal reasons. These two terms tend to be used in differing contexts to mean similar things, although there is a tendency for the USA to continue to use the term 'travel' when in fact 'tourism' is meant (Page \& Connel, 2009).

The results of an analysis and research of territory requirements have shown great potential for the purpose of tourism development. Traffic isolation still present today had its positive sides such as a high improbability of uncontrolled and hyper productive growth of unorganised tourism that would generate negative effects for the tourist destination on the exponential scale over a long period.

Two factors contribute to the attractivness of a tourist destination. The primary elements are: climate, ecology, cultural tradition, traditional architecture and landscape. The secundary elements are the ones correlated with tourism development: hotels, terciary services, transport, activities, entertainment. The difference between the two often indicates the main characteristics of many tourist destinations. The tourists usually enjoy primary elements, such as beaches, cathedrals etc., without 
directly paying for its maintainence eventhough they exsist. The development of the tourist industry, however, depends on secundary elements available in that tourist destination that are often, due to commercial organisations that are the providers, quite expensive.

In recent years, increasing attention has been paid to the effects of tourism and related developments upon the environment of 'destination areas'. The increasing popularity of the concept of sustainable development has resulted in tourism being viewed as an activity which could easily be developed along those appropriate lines. It is argued, however, that such a viewpoint is often simplistic and naïve, because of a lack of understanding of the complex nature of tourism. While tourism is dependent upon the environment for much of its well-being, the prevailing lack of knowledge, responsibility, and long-term planning, has often resulted in development which is neither environmentally nor culturally sympathetic to the host area and community.

It is necessary to appreciate that tourist destination areas evolve and change over time, both responding to, and being altered by, changes in tourism. They are not static environments, and need responsible and pro-active planning and management. Reliance upon local initiatives, uncoordinated planning, and self-regulation in a situation of ill-defined responsibility, will not result in a secure long-term future for either the tourist industry or the environment of the destination area. Coordination of policies, pro-active planning, acceptance of limitations on growth, education of all parties involved, and commitment to a long-term viewpoint, are prerequisites to the successful linking of tourism and sustainable development.

There are a number of barriers which make comparisons between transport and tourism trips difficult or inoperable. For example, there is little co-ordination of data collection; transport and tourism data are inconsistent and definitional problems as to what is being measured are problematic. Indeed, some transport operators would argue that they do not actually carry tourists but only a homogenous group they label passengers. This dated perspective is losing ground with many larger operators applying marketing techniques to differentiate between market segments such as tourist and leisure travel. Thus, the definitions, which have been almost universally applied in transport studies, are not formulated similarly in tourism. In transport, for example, a trip involves a movement of a person between two places in order for activities to be undertaken. Places are usually referred to as originating and destination zones. In transport studies, a trip can be undertaken by using one mode of transport only or several modes. Furthermore, the trip can be divided into trip legs, each leg being a section of the overall trip made by one mode. The duration of the trip is the time between the start and finish of a journey. A tour refers to more than one trip from an originating zone to other places, but finally returning to the base destination zone. Tourism studies draw on a parallel framework but the conceptual base and definitions often differ. For example, the terms "trip" and "tour" are less clearly specified in tourism than in transport studies. Journey purpose is also defined differently in that transport trips can be made for work, leisure, and educational purposes whereas tourism trips include business, pleasure, visiting friends and relatives, health and religion. There are currently attempts to harmonise conceptual frameworks and data collection, mainly in relation to long distance travel, but they are still in gestation.(Lumsdon \& Page, 2004). 
The territory that is observed for the construction of the new railway has a certain potential in the development of rural and eco tourism. Table 1. presents us with some of the natural locations on the mentioned territory:

\begin{tabular}{|c|c|c|c|c|}
\hline $\begin{array}{l}\text { CATEGORYOF } \\
\text { PROTECTION }\end{array}$ & $\begin{array}{c}\text { THE NAME OF THE } \\
\text { LOCATION }\end{array}$ & $\begin{array}{l}\text { SURFACE/ } \\
\text { ha }\end{array}$ & $\begin{array}{l}\text { PROTECTION } \\
\text { IMPLEMENT- } \\
\text { ATION }\end{array}$ & REGISTRY NUMBER \\
\hline \multicolumn{5}{|l|}{ SPECIAL RESERVATES } \\
\hline $\begin{array}{l}\text { Geografical- } \\
\text { botanical }\end{array}$ & ĐURĐEVAČKI PIJESCI & 19,5 & 01.02 .1963$. & $87-1963$ \\
\hline \multicolumn{5}{|l|}{ Botanical } \\
\hline \multirow[t]{2}{*}{ Forest } & DUGAČKO BRDO & 10,91 & 30.03 .1973 . & $680-1973$ \\
\hline & CRNI JARKI & 72,25 & 4.10 .1992 & \\
\hline \multirow[t]{2}{*}{ Animals } & VELIKI PAŽUT & 1000 & 10.12.1998. & - \\
\hline & & & & \\
\hline \multicolumn{5}{|l|}{$\begin{array}{l}\text { PROTECTED } \\
\text { LANDSCAPES }\end{array}$} \\
\hline & KALNIK & 4200 & 19.04.1985. & $798-1985$ \\
\hline & ČAMBINA & 50 & 1999. & - \\
\hline \multicolumn{5}{|l|}{ NATURE MONUMENT } \\
\hline & FIELDS IN ZOVJE NEAR ĐELEKOVEC & 1 & 24.08 .2000 & - \\
\hline & $\begin{array}{l}\text { OLD TREE OF SWEET CHESNUT (k.o. } \\
\text { Koprivnica) }\end{array}$ & - & 2001 & - \\
\hline \multicolumn{5}{|l|}{$\begin{array}{l}\text { MONUMENT OF PARK } \\
\text { OF ARCHEOLOGY }\end{array}$} \\
\hline & PARK IN KRIŽEVCI & 1,41 & 15.12 .1971$. & $651-1971$. \\
\hline & PARK IN KRIŽEVCI & 1,33 & 15.12.1971. & $652-1971$. \\
\hline PROTECTED AREAS & REGIONAL PARK MURA-DRAVA & 87.680 & 02.2104 & - \\
\hline
\end{tabular}

Tab. 1. Natural locations on the territory of the new railway, authors interpretation, DZS (2013). Tourism - collective datas, 2013

For touristic journeys we use the most modern transportation available but, nonetheless, we also have some interesting transportation that was once a peak of technology and today they represent a potential tourist attraction for some tourist destinations. With the increase of traffic development, as a direct consequence of increased tourist circulation, we can see the increase in number of different problems that are primarily correlated with growth, development and dimensioning of traffic capacities and also the organisation and safety of traffic.

Traffic growth also causes an elevated level of landscape pollution such as ecological or territorial i.e. Visual clutter.

\section{Conclusion}

The introduction of a new railway infrastructure should be a generator of an economically sustainable tourist development. Putting tourism development as a priority over traffic development can be explained by choosing longer and, by that, more expensive routes for the construction of traffic infrastructure. This occurs often because of ecological preservation and, by doing that, preserving a good percentage of natural resources. The concept of sustainable tourist development indicates a necessity of optimal use of environment resources that are the foundation of tourist 
development and by doing that keeping the important ecological processes intact and helping the protection and preservation of natural heritage and biodiversity. The correlations of interdependence of traffic and tourism are very complex. The priority is an analysis of economic and social factors of the territory where the new infrastructure will be implemented. Traffic planning cannot be founded on pure satisfaction of traffic demand anymore hence it has to control traffic growth and channel it through the modelling of options of sustainable development. In the same time on the territory in question it is required to investigate the traffic demand of passenger and cargo transport and the consequences of the new railway infrastructure implementation regarding environment control. The limitations imply development limitations of traffic in a certain area. Traffic infrastructure and means permits a certain level of control over tourism. The reason is a large mixture of positive and negative consequences and a great variety of combinations of the two. With large levels of pollution and low level of traffic safety tourism development suffers great damage not to mention the impact on everyday life and economy of the society. First step is to make a development plan of traffic infrastructure towards and within the territory of the tourist destination. This allows the possibility to choose one of the possible traffic vectors and to regulate traffic infrastructure density. In the same time, bearing in mind the choice of the destination and possible negative effects of the infrastructure, there has to be certain awareness that a tourist offer can also be developed gradually.

\section{Acknowledgements}

This thesis was written based on author work and research on the making of Traffic Technology Study as a part of the project "A Study of Basic Possibility of new railway construction on the line Koprivnica - Kotoriba - State border", 2014.

\section{References}

The Development Strategy of Croatian Tourism, 2003-2010., Hotel Partner d.o.o., 2003

Rados, B. (2014). Traffic Technology Study of Basic Possibility of new railway construction on the line Koprivnica - Kotoriba - State border, Zagreb

Pavlic, I.(2009). The characteristics and specific features of modern tourist demand, Annals of DAAAM \& Proceedings Publisher, COPYRIGHT 2009 DAAAM International Vienna ISSN: 1726-9679

Page, S.; Connell, J. (2009). Tourism: A modern synthesis, Third Edition, ISBN: 9781-40800-916-1, UK

Lumsdon, L.;Page, S. (2004).Tourism and transport, Elsevier, ISBN: 0-08-044172-6, The Netherlands

DZS (2013). Tourism - collective datas, 2013.,4.3.2/11., Zagreb, http://www.dzs.hr $(20.1 .2014)$ 